(6)

OPEN ACCESS

\title{
Subarachnoidal fat droplet deposition and fat embolism syndrome
}

\author{
Keisuke Yamamoto, Shigeki Kushimoto
}

Division of Emergency and Critical Care Medicine, Tohoku University Graduate School of Medicine, Sendai, Japan

\section{Correspondence to} Professor Shigeki Kushimoto, kussie@emergency-medicine. med.tohoku.ac.jp

Accepted 11 October 2017

\section{(1) \\ CrossMark}

To cite: Yamamoto $\mathrm{K}$, Kushimoto S. BMJ Case Rep Published Online First: [please include Day Month Year]. doi:10.1136/bcr-2017221493

\section{DESCRIPTION}

A 68-year-old woman presenting with multiple rib, spine fractures, femur and ankle fractures after a fall from height was admitted. Although she responded to verbal orders appropriately at the time of admission, her consciousness drastically deteriorated after 4.5 hours of the accident. She presented a decerebrate posture and acute respiratory failure with bilateral diffuse infiltration consistent with non-cardiogenic pulmonary oedema, requiring mechanical ventilation. She was also complicated with decreased platelet count, suggesting fat embolism

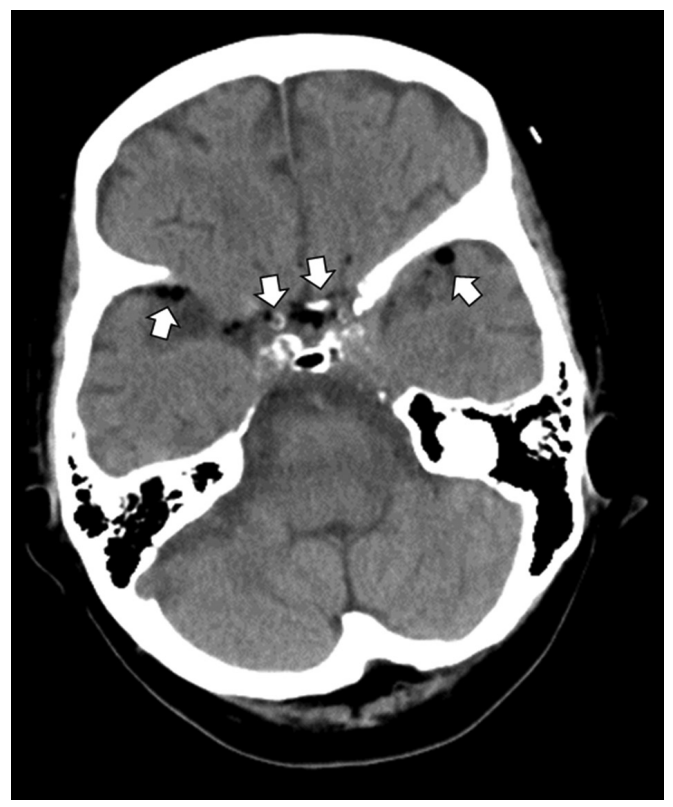

Figure 1 Brain CT shows low-density fat droplets in the subarachnoid space as indicated by arrows (Hounsfield unit of -50$)$.

\section{Learning points}

- The relationship between fat embolism syndrome and subarachnoidal fat droplet deposition might be reminded as-yetunevaluated condition.

- A careful consideration of brain CT findings (round hypodense lesions with negative values of Hounsfield unit) may be useful to confirm clinical suspicion of cerebral fat embolism.

syndrome (FES). At the time of the acute deterioration, brain CT demonstrated no gross abnormality, except for fat droplet in the subarachnoidal space (figure 1). On the third day, MRI showed numerous pinpoint hyperintense foci in the grey and white matter of the cerebral and cerebellar hemispheres on diffusion-weighted images (figure 2), consistent with the 'starfield appearance'. Right to left shunt, including patent foramen ovale, was not evident by transthoracic ultrasonography. Although the findings on MRI improved, the fat droplet deposition in the subarachnoidal space was persistent for over 3 months. Patient's neurological recovery was limited to severe disability.

FES is a well-known complication of long bone fractures. ${ }^{1}$ Although a causative relationship has never been suggested, this patient demonstrated both the finding of 'starfield' appearance ${ }^{2}{ }^{3}$ and persistent 'subarachnoidal fat droplet deposition'. Clinicians should consider FES in patients with the combined presentation of recent long bone fractures, hypoxaemia and impairment of consciousness. The relationship between FES and subarachnoidal fat droplet might be reminded as-yet-unevaluated condition. 
Contributors Both authors cared for the patient, contributed to writing of the report and approved final version of the manuscript.

Competing interests None declared.

Patient consent Detail has been removed from this case description/these case descriptions to ensure anonymity. The editors and reviewers have seen the detailed information available and are satisfied that the information backs up the case the authors are making.

Provenance and peer review Not commissioned; externally peer reviewed.

Open Access This is an Open Access article distributed in accordance with the Creative Commons Attribution Non Commercial (CC BY-NC 4.0) license, which permits others to distribute, remix, adapt, build upon this work non-commercially, and license their derivative works on different terms, provided the original work is properly cited and the use is non-commercial. See: http://creativecommons.org/ licenses/by-nc/4.0/

(c) BMJ Publishing Group Ltd (unless otherwise stated in the text of the article) 2017. All rights reserved. No commercial use is permitted unless otherwise expressly granted.

\section{REFERENCES}

1 Caricato A, Russo G, Biasucci DG, et al. Fat embolism syndrome. Intensive Care Med 2017:43:1411-2

2 Goenka N, Ropper AH. Images in clinical medicine. Cerebral fat embolism. N Engl J Med 2012:367:1045

3 Scarpino M, Lanzo G, Cappelli F, et al. Cerebral fat embolism after video-assisted thoracic surgery. Ann Thorac Surg 2016;102:e409-11.

Copyright 2017 BMJ Publishing Group. All rights reserved. For permission to reuse any of this content visit

http://group.bmj.com/group/rights-licensing/permissions.

BMJ Case Report Fellows may re-use this article for personal use and teaching without any further permission.

Become a Fellow of BMJ Case Reports today and you can:

- Submit as many cases as you like

- Enjoy fast sympathetic peer review and rapid publication of accepted articles

- Access all the published articles

Re-use any of the published material for personal use and teaching without further permission

For information on Institutional Fellowships contact consortiasales@bmjgroup.com

Visit casereports.bmj.com for more articles like this and to become a Fellow 